\title{
Wetsvoorstellen voor een eerlijke economie
}

\author{
Mr.J.E. Devilee
}

\begin{abstract}
In deze bijdrage worden twee van de drie wetsvoorstellen voor een 'eerlijke economie' aan een kritische evaluatie onderworpen. Uit de historische en actuele schets die volgt, blijkt dat de wens om tot versterking van de positie van werknemers te komen bijzonder toepasselijk is in het huidige tijdsgewricht, waarin de factor arbeid op verschillende niveaus aan betekenis heeft ingeboet.
\end{abstract}

\section{Inleiding}

Op 17 september 2020 presenteerde de SP drie voorontwerpen van wetsvoorstellen voor een 'eerlijke economie': het wetsvoorstel Eerlijker Inkomen, het wetsvoorstel Eerlijk Delen en het wetsvoorstel Eerlijk Beslissen. Respectievelijk zien deze voorstellen op een verhoging van het minimumloon, verplicht aandeelhouderschap voor werknemers van grote ondernemingen en zeggenschap voor werknemers ten aanzien van de strategie van grote ondernemingen. Een vennootschap is een grote onderneming, in de zin van de wetsvoorstellen, indien er meer dan honderd personen werkzaam zijn. Met name het wetsvoorstel Eerlijk Delen en het wetsvoorstel Eerlijk Beslissen, beide ingediend door Tweede Kamerlid Alkaya, beogen een radicale wijziging ten gunste van de factor arbeid teweeg te brengen in het vennootschapsrecht. Niet alleen zullen werknemers automatisch meedelen in de gemaakte winsten, ook kunnen zij de besluitvorming in de algemene vergadering beïnvloeden en zo een soort natuurlijke bescherming vormen tegen ongewenst aandeelhoudersactivisme door andere aandeelhouders die slechts geïnteresseerd zijn in hoge winsten op korte termijn, zonder daarbij betrokkenheid te tonen bij de langetermijngroei en -ontwikkeling van het bedrijf. Bovendien zullen werknemers een actievere rol kunnen aannemen wat betreft de strategievorming door het bestuur van de vennootschap. Althans, dat is de ideële gedachte achter de voorstellen. De initiatiefnemer spreekt over de noodzaak van een 'nieuwe en eerlijke machtsbalans' in ondernemingen. ${ }^{1}$

De wetsvoorstellen vormen een nieuw hoofdstuk in het boek over de 'publicisering' van het privaatrecht. ${ }^{2}$ De overheid

\footnotetext{
Mr. J.E. Devilee is als promovendus verbonden aan het Molengraaff Instituut voor Privaatrecht van de Universiteit Utrecht.

1. Zie www.sp.nl/nieuws/2020/09/sp-komt-met-drie-wetten-vooreerlijke-economie.

2. C. Jansen, Noodwetgeving en privaatrecht. Ervaringen naar aanleiding van eerdere mondiale crises, NJB 2020/1316, p. 1514-1516.
}

intervenieerde in de loop van de vorige eeuw steeds meer tussen private partijen, ten gunste van de bescherming van de zwakkere partij en het algemeen belang. Dit wettelijk ingrijpen was een uiting van de visie dat het privaatrecht een 'sociale roeping' had. Met een beroep op de belangen van de gemeenschap als geheel werden de contractsvrijheid, de vrijheid van de eigenaar en de vrijheid van de ondernemer beperkt ten gunste van het collectief. In deze bijdrage bespreek ik de inhoud van het wetsvoorstel Eerlijk Delen (zowel de consultatieversie als de gewijzigde versie die op 11 december 2020 is ingediend bij de Tweede Kamer) en het wetsvoorstel Eerlijk Beslissen, gevolgd door enkele beknopte kanttekeningen die daarbij gemaakt kunnen worden. ${ }^{4}$ Hieruit blijkt dat de wetsvoorstellen niet uitblinken in hun doordachtheid. Uit de historische schets die volgt, zal echter naar voren komen dat de maatschappelijke ontwikkeling waar de wetsvoorstellen op ingrijpen wel degelijk aandacht verdient. Niet alleen wat betreft het achterblijven van de lonen ten opzichte van de winsten die bedrijven maken, maar ook wat betreft de afname van de relevantie van de vennootschapsrechtelijke medezeggenschap. De wetsvoorstellen voor een eerlijke economie zijn in die zin een sign of the times. Betoogd zal worden dat het welzeker van betekenis is voor ondernemingsrechtjuristen om zich met dit onderwerp bezig te houden.

\section{Schets van de inhoud van de voorstellen}

\subsection{Eerlijk Delen}

Via het wetsvoorstel Eerlijk Delen wil de SP het 'doorgeschoten aandeelhouderskapitalisme' beëindigen of op zijn minst van een tegenkracht voorzien. Het middel dat daartoe in dit wetsvoorstel wordt aangedragen, is zowel radicaal als ogenschijnlijk simpel: grote bedrijven worden verplicht om hun werknemers tot kernonderdeel van hun aandeelhoudersbasis

3. Jansen 2020, p. 1514. Jansen zelf gebruikt de term 'uithollen'.

4. Twee kanttekeningen bij het wetsvoorstel Eerlijk Delen worden hierbij buiten beschouwing gelaten, maar kwamen wel naar voren in de consultatiereacties. Ten eerste het feit dat geen aandacht wordt besteed aan de mogelijkheid dat een $10 \%$-belang van de STAK in een dochtermaatschappij de fiscale eenheid van een concern kan doorbreken. Ten tweede dat het wetsvoorstel er, bij de vennootschappen waarop het van toepassing is, voor zorgt dat het voor een koper of bieder in een overnamesituatie onmogelijk wordt om alle aandelen in de vennootschap te verkrijgen, omdat het $10 \%$-aandelenbelang van de STAK niet vervreemdbaar is. Zie hiervoor de reacties van VNO-NCW, de Gecombineerde Commissie Vennootschapsrecht van de Nederlandse Orde van Advocaten en de Koninklijke Notariële Beroepsorganisatie (GCV) en Marnix Holtzer. 
te maken via een daartoe speciaal opgerichte stichting. Alle kapitaalvennootschappen (BV's en NV's) die honderd werknemers of meer in dienst hebben, dienen op verzoek van de Ondernemingsraad (hierna: OR) een Stichting Administratiekantoor (hierna: STAK) op te richten. Deze STAK verkrijgt en houdt aandelen in de vennootschap en heeft mede als doel: 'het uitgeven van royeerbare certificaten aan de in de onderneming krachtens een arbeidsovereenkomst werkzame personen, naar rato van het aantal gewerkte uren in het kalenderjaar voorafgaand aan de uitgifte, tegenover het op eigen naam ten titel van administratie verkrijgen en houden van aandelen in de vennootschap'. Elk jaar zullen dus royeerbare certificaten van aandelen aan alle werknemers worden uitgedeeld naar rato van het aantal gewerkte uren in het voorafgaande kalenderjaar. Deze aandelen mogen niet worden vervreemd of bezwaard door de STAK, tenzij werknemers hun certificaten wensen in te ruilen voor aandelen (royement). ${ }^{6}$

In afwijking van artikel 2:96/206 BW, dat goedkeuring van de algemene vergadering (hierna: AV) voorschrijft bij aandelenuitgifte, zal een wetsartikel worden geintroduceerd dat bepaalt dat de NV/BV jaarlijks $1 \%$ van het aantal door de vennootschap uitgegeven aandelen zal uitgeven aan de STAK totdat zij $10 \%$ van de aandelen bezit (een afwijking naar boven is toegestaan). Ook worden bepalingen in de wet opgenomen die ervoor zorgen dat (1) de vennootschap geen machtiging van de AV nodig heeft om eigen aandelen in te kopen om aan de STAK uit te geven, en (2) de overige aandeelhouders geen voorkeursrecht hebben op de aandelen die aan de STAK worden uitgegeven. ${ }^{7}$ Zo wordt verzekerd dat de uitzonderingen die de wet momenteel bevat ten gunste van aandelen die worden uitgegeven aan werknemers, ook gaan gelden voor de STAK waaraan werknemersaandelen worden uitgegeven. Hiermee wordt de onzekerheid over de vraag of deze uitzonderingen ook voor werknemersrechtspersonen gelden weggenomen. ${ }^{8}$ De STAK heeft het beheer over de aandelen en zal het aan de aandelen verbonden stemrecht uitoefenen. Het bestuur van de STAK zal worden gevormd door de leden van de OR.

Wie de memorie van toelichting bestudeert, leest dat de indiener van het wetsvoorstel hoopt dat het bezit van een tiende van het aandelenkapitaal zal zorgen voor een sterk blok in de

5. Art. 1 lid 1 onder a wetsvoorstel Eerlijk Delen (www.internetconsul tatie.nl/weteerlijkdelen). In tegenstelling tot niet-royeerbare certificaten van aandelen kunnen royeerbare certificaten van aandelen worden omgewisseld voor gewone aandelen. Zie R.A. Wolf, De kapitaalverschaffer zonder stemrecht in de BV (VDHI nr. 116; diss. Maastricht), Deventer: Kluwer 2013, p. 121-122.

6. Art. 1 lid 2 wetsvoorstel Eerlijk Delen. Het vervreemden en het bezwaren van de aandelen zijn uitgesloten van het doel van de stichting. Onder vervreemden is niet begrepen de overdracht van aandelen bij royement van de certificaten.

7. Hiertoe worden art. 2:96a/206a lid 1 en 2:98 lid 5 BW gewijzigd.

8. Deze discussie ontstond met name naar aanleiding van art. 2:96a BW, zie Asser/Van Olffen \& Rensen 2-IIa 2019/351, Kemperink, in: Sdu Commentaar Ondernemingsrecht 2020, art. 96a en A. Voûte, Aandelen voor werknemers. Motivatie door participatie (diss. Nijmegen), Deventer: Kluwer 1991, p. 172-173. aandeelhoudersvergadering, dat daar met een andere intentie zit dan de gemiddelde aandeelhouder. Deze gemiddelde aandeelhouder is volgens hen te veel gericht op de korte termijn en heeft het bestuur van grote vennootschappen de laatste decennia succesvol onder druk weten te zetten om zo snel mogelijk zo veel mogelijk winst uit te keren. Dit is ten koste gegaan van werknemers, die hun lonen zien achterblijven bij de hoge winsten die bedrijven realiseren. Ook zijn bestuurders zich meer gaan richten op de kwartaalresultaten, wat ten koste gaat van (onzekere) langetermijninvesteringen in het bedrijf.9 Door werknemers onderdeel uit te laten maken van het aandeelhoudersbestand hoopt de indiener beide - als negatief bestempelde - effecten tegen te gaan. Men verwacht dat werknemers, vertegenwoordigd door de OR, een andere stem zullen laten horen ter vergadering omdat zij een grotere betrokkenheid zullen voelen met de continuiteit van de onderneming die in stand wordt gehouden door de vennootschap. Zeker bij beursgenoteerde vennootschappen zullen aandeelhouders in de vorm van werknemers meer geneigd zijn om zich te concentreren op het ondernemingsbelang dan de rest van het aandeelhoudersbestand, dat wordt gedomineerd door internationaal beleggend publiek dat zich puur focust op het behalen van een zo hoog mogelijk rendement. ${ }^{10}$

\subsection{Eerlijk Beslissen}

Het wetsvoorstel Eerlijk Beslissen is bedoeld als aanvulling op de wet Eerlijk Delen en ziet op een uitbreiding van de Wet op de ondernemingsraden (WOR) wat betreft ondernemingen met meer dan honderd medewerkers. ${ }^{11}$ De opstellers van het wetsvoorstel willen dat de $\mathrm{OR}$ van deze grote ondernemingen kan meebeslissen over de koers van de onderneming, en zeggenschap verkrijgt over strategische besluiten. Om dit te bereiken wordt voorgesteld dat aan OR's van grote ondernemingen een instemmingsrecht wordt toegekend ten aanzien van belangrijke besluiten. Net als bij het wetsvoorstel Eerlijk Delen wordt ook hier een middel aangedragen dat zowel radicaal als ogenschijnlijk simpel is: alle adviesplichtige besluiten (art. 25 WOR) worden bij grote ondernemingen simpelweg tot instemmingsrechtelijke besluiten getransformeerd. Het gaat dan onder meer om besluiten zoals de overdracht van de zeggenschap over de onderneming, een belangrijke inkrimping of uitbreiding, een belangrijke wijziging in de verdeling van de bevoegdheden binnen de onderneming of het doen van een belangrijke investering. Daarnaast krijgt de OR een extra instemmingsrecht betreffende besluiten over de verhoging van de beloning van bestuurders en commissarissen. ${ }^{12}$ De wijziging zal wetstechnisch als volgt vorm krijgen. Artikel 25 WOR, dat de adviesplichtige besluiten opsomt, gaat gelden voor ondernemingen waarin minder dan honderd personen werkzaam zijn. Artikel 27 WOR krijgt een nieuw lid, dat zal bepalen dat alle

9. MvT wetsvoorstel Eerlijk Delen (www.internetconsultatie.nl/ weteerlijkdelen), p. 2.

10. MvT wetsvoorstel Eerlijk Delen, p. 3-4.

11. Wetsvoorstel Eerlijk Beslissen, MvT wetsvoorstel Eerlijk Beslissen, p. 1 (beide: www.internetconsultatie.nl/weteerlijkbeslissen).

12. Het is onduidelijk of wordt gedoeld op het bezoldigingsbeleid in zijn algemeenheid of dat men individuele beloningen op het oog heeft. 
besluiten waarvoor ingevolge artikel 25 WOR een adviesrecht geldt, bij ondernemingen met meer dan honderd werknemers onderworpen zullen zijn aan het instemmingsrecht. De versterkte positie van de OR die hier het gevolg van is, moet bewerkstelligen dat bestuurders 'daadwerkelijk andere keuzes gaan maken' omdat zij een verantwoordingsplicht voelen en tonen aan andere belanghebbenden dan aandeelhouders. ${ }^{13}$ Het wetsvoorstel bevat tot slot een opmerkelijke bepaling van puur symbolische aard, die verplicht dat de verkiezingen voor de OR zullen plaatsvinden op 1 mei (de Dag van de Arbeid).

\section{Kanttekeningen bij het toepassingsbereik van de wetsvoorstellen}

Een eerste kanttekening bij het wetsvoorstel Eerlijk Delen betreft de ingestelde grens van honderd werknemers. Dit doet denken aan een van de toepassingscriteria om een vennootschap als structuurvennootschap aan te merken, maar de analogie is onvolledig. In de structuurregeling is namelijk voorzien in de situatie dat de vennootschap onderdeel uitmaakt van een concern. De werknemers van het concern worden dan toegerekend aan de vennootschap die mogelijkerwijs onder het structuurregime valt. De wet bepaalt daartoe dat er 'bij de vennootschap en haar afhankelijke maatschappijen tezamen [curs. JD] in de regel ten minste honderd werknemers in Nederland werkzaam zijn'. ${ }^{14}$ Het wetsvoorstel Eerlijk Delen voorziet niet in situaties waarin concernverhoudingen spelen. Hier is in consultatie door meerdere partijen op gewezen. ${ }^{15}$ Het wetsvoorstel Eerlijk Beslissen hanteert net als het wetsvoorstel Eerlijk Delen een grens van honderd werknemers, maar hier ligt deze keuze meer voor de hand omdat dit past bij de systematiek van de WOR. Daar wordt het al dan niet van toepassing zijn van de bepalingen van de WOR namelijk reeds gekoppeld aan het aantal werknemers dat de onderneming telt.

$\mathrm{Bij}$ het gekozen toepassingsbereik van alle vennootschappen met meer dan honderd werknemers valt nog een kanttekening te maken. De keuze impliceert dat deze vennootschappen veel met elkaar gemeen hebben. Men lijkt er in beide wetsvoorstellen van uit te gaan dat bij deze vennootschappen sprake is van een 'ontspoord aandeelhouderskapitalisme'. ${ }^{16}$ Via de wetsvoorstellen wil men dit ontspoorde aandeelhouderskapitalisme beteugelen, zodat de economie meer kan functioneren 'in ons aller belang op de lange termijn'. ${ }^{17}$ Maar in hoeverre is deze aanname houdbaar? Met name familiebedrijven, ook die met meer dan honderd werknemers, denken bijvoorbeeld niet in bestuurstermijnen maar in generaties. Kenmerkend voor dit

13. MvT wetsvoorstel Eerlijk Beslissen, p. 2.

14. Art. 2:153/263 lid 2 onder c BW. Art. 2:152/262 BW bevat de wettelijke definitie van een afhankelijke maatschappij.

15. Zie de consultatiereacties van VNO-NCW, SBI Formaat en de GCV.

16. MvT wetsvoorstel Eerlijk Delen, p. 2. MvT wetsvoorstel Eerlijk Beslissen, p. 1 heeft het over 'op korte termijn gerichte aandeelhouders' die de Rijnlandse traditie onder druk zetten in het tijdperk van het 'doorgeschoten aandeelhouderskapitalisme'.

17. MvT wetsvoorstel Eerlijk Delen, p. 2; MvT wetsvoorstel Eerlijk Beslissen, p. 2. type bedrijven is juist dat de onderneming een hechte gemeenschap vormt die langdurige banden onderhoudt met haar stakeholders, in het bijzonder met de werknemers. ${ }^{18}$ De familieleden voelen doorgaans een sterke emotionele binding met de onderneming, en wensen de aandelen in eigen handen te houden. ${ }^{19}$ Waarom zouden deze bedrijven op één lijn worden gesteld met bedrijven waar sprake is van 'ontspoord aandeelhouderskapitalisme'? Ook wordt geen onderscheid gemaakt tussen beursgenoteerde BV's/NV's en niet-beursgenoteerde BV's/NV's. Dit maakt echter nogal een verschil uit voor de samenstelling en vloeibaarheid van het aandeelhoudersbestand. Een beursgenoteerde vennootschap staat in grotere mate bloot aan de druk die aandeelhouders (en de financiële markten) op het bestuur uitoefenen om elk kwartaal met goede (winst)cijfers te komen, dan een niet-beursgenoteerde vennootschap. Voor beursgenoteerde vennootschappen is het onder de wet Eerlijk Delen bovendien relatief gemakkelijk om aandelen uit te geven, omdat de waardebepaling en verhandelbaarheid reeds helder zijn. Bij een niet-beursgenoteerde vennootschap moet dit nog worden vastgesteld. Dit vergt een procedure die tijd, geld en openheid van informatie vraagt. In een interview in het FD zei Van Beusekom begin deze eeuw dat niet-beursgenoteerd zijn een 'flinke handicap' is bij het uitgeven van werknemersaandelen of opties:

'De structuren binnen veel bedrijven zijn afgestemd op de directeur-grootaandeelhouder of enkele aandeelhouders. $\mathrm{Er}$ is een verwevenheid met pensioenvoorzieningen, taxplanning, winstverdeling etc. Van Beusekom: "Wil je het personeel laten participeren, dan moet je de zaak transparant maken. Beschouw het maar als een interne beursgang." 20

Tot slot wijzen twee van de consultatiereacties bovendien terecht op het feit dat ook andere rechtsvormen grote ondernemingen in stand kunnen houden, zoals coöperaties, onderlinge waarborgmaatschappijen en verenigingen. ${ }^{21}$

\section{Kanttekeningen bij de toekenning van financiële rechten in het wetsvoorstel Eerlijk Delen}

Naast vragen rondom het toepassingsbereik van de wetsvoorstellen, zijn er ook praktische vragen. Bijvoorbeeld omtrent de financiering van de te verkrijgen aandelen. Alles rondom het

18. A.J.S.M. Tervoort, Familievennootschappen: onderscheidende kenmerken en juridische structureringsinstrumenten, in: A.J.S.M. Tervoort e.a., Familievennootschappen (IVOR nr. 107), Deventer: Wolters Kluwer 2017 , p. 5-6. Ook de consultatiereactie van de GCV benoemt dat familiebedrijven 'haast vanzelfsprekend zijn gericht op lange termijn waardecreatie'.

19. Tervoort 2017, p. 6. E. Poutsma, R. Mol \& M. van Beusekom, Financiële werknemersparticipatie. Trends en cijfers in Nederland, TvA (14) 1998, afl. 2, p. 193 wijzen op de terughoudendheid bij deze bedrijven wat betreft aandelenparticipatie voor werknemers, juist omdat de wens heerst het bedrijf in familiehanden te houden.

20. Voor werknemersaandelen is een 'interne beursgang' nodig, FD 14 augustus 2000. M. van Beusekom was eind jaren negentig directeur van het Nederlands Participatie Instituut, dat werknemersparticipatie wil bevorderen.

21. Zie de consultatiereacties van de GCV en SBI Formaat. 


\section{Maandblad}

Ondernemingsrecht

wetsvoorstel Eerlijk Delen ademt de sfeer dat deze kosten door de winst/reserves van de vennootschap worden gedragen, maar een concrete uitwerking ontbreekt. Zo besteedt het wetsvoorstel geen aandacht aan de stortingsplicht op de aandelen en de mogelijkheid tot financiële steunverlening voor werknemersaandelen die de wet bevat (art. 2:98c BW). Noch wordt er gesproken over de situatie dat het eigen vermogen van de vennootschap het niet toelaat dat dergelijke uitgaven door de vennootschap worden gedaan (vgl. art. 2:98 lid $2 \mathrm{BW}$ ). Als de strekking van het wetsvoorstel is om de verkrijging van werknemersaandelen zo gemakkelijk mogelijk te maken, doet men er goed aan om ook aan de financiering van de aandelen aandacht te besteden, zodat zo min mogelijk financiële hindernissen hoeven te worden genomen door werknemers. De vele vragen rondom de financiering van de aandelen kwamen ook naar voren in de consultatiereacties. ${ }^{22}$ De indiener van het wetsvoorstel heeft naar aanleiding van deze kritiek op 11 december 2020 een aangepast voorstel ingediend bij de Tweede Kamer, waarin is bepaald dat de aandelen om niet aan de STAK worden verstrekt. Bovendien wordt de mogelijkheid geïntroduceerd om de uitgifte van deze aandelen te onderwerpen aan een uitzondering op de stortingsplicht. $^{23}$

Er springen nog meer praktische vragen ten aanzien van de opzet van het wetsvoorstel in het oog, zoals: wat gebeurt er als er werknemers bij komen, terwijl de STAK al 10\% van de uitgegeven aandelen houdt en alle certificaten vergeven zijn? Vindt er simpelweg elk jaar een 'herverdeling' van de certificaten over alle werknemers plaats, waarbij de verhoudingen worden berekend aan de hand van het aantal gewerkte uren? Dit oogt omslachtig, aangezien dit met zich mee zal brengen dat iedere werknemer elk jaar recht heeft op een wisselende hoeveelheid certificaten. De royeerbaarheid van de certificaten staat een efficiënte afwikkeling van deze jaarlijkse verplichting nog verder in de weg in die gevallen dat certificaten zijn omgewisseld voor aandelen. $\mathrm{Na}$ royering zijn de aandelen bovendien niet meer in bezit van de STAK, zodat men in theorie jaarlijks kan overgaan tot het royeren van $1 \%$ van de certificaten. Hierdoor zal de 10\%-grens van de STAK nimmer worden bereikt. Meer voor de hand ligt dan ook het verstrekken van niet-royeerbare certificaten. Dit ondervangt meteen de geuite kritiek in consultatie dat de royeerbaarheid ervoor kan zorgen dat werknemers juist blootgesteld worden aan een prikkel om hun certificaten te royeren en de aandelen te verkopen op het moment dat de koers piekt, en derhalve het probleem van kor-

22. Zie de consultatiereacties van VNO-NCW, Eumedion, Marnix Holtzer en de GCV.

23. Kamerstukken II 2020/21, 35672, nr. 2. De uitzondering op de stortingsplicht wordt vormgegeven via een toevoeging aan art. 2:80 lid 3 en 2:191 lid 2 BW. tetermijngerichtheid juist versterkt. ${ }^{24}$ Verder zou men kunnen overwegen om alle werknemersaandelen bij de door de OR bestuurde STAK te plaatsen, zodat de OR een permanente zeggenschapspositie in de AV krijgt, terwijl gelijktijdig een winstdelingsregeling voor het personeel wordt verplicht. ${ }^{25}$ Dit vergemakkelijkt meteen de gang van zaken rondom de beëindiging van het dienstverband. Het wetsvoorstel voorziet niet in een antwoord op de vraag wat er in een dergelijk geval gebeurt met de (certificaten van) aandelen van de betreffende werknemer. Een winstdelingsregeling biedt hier voordelen, aangezien deze contractrechtelijk van aard is en per werknemer gemakkelijk kan worden afgewikkeld bij de beëindiging van de arbeidsovereenkomst. De kritiekpunten uit deze paragraaf kwamen veelvuldig terug in de consultatiereacties op het wetsvoorstel. ${ }^{26}$ Ook hieraan lijkt gedeeltelijk gehoor te zijn gegeven in de gewijzigde versie van het wetsvoorstel die op 11 december 2020 is ingediend bij de Tweede Kamer. Hierin is niet langer sprake van royeerbare, maar van niet-royeerbare en niet-verhandelbare certificaten. Tevens is de eis dat de uitdeling van certificaten geschiedt naar rato van het aantal gewerkte uren geschrapt uit de doelomschrijving van de STAK. Uit de memorie van toelichting valt evenwel af te leiden dat deze eis niet geheel is losgelaten, aangezien het aantal gewerkte uren daar terugkeert als maatstaf voor de berekening van de hoogte van de individuele winstuitkering. De werknemers ontvangen 'als collectief een percentage van de winst, corresponderend met het percentage van de aandelen dat in bezit is van de STAK, waarna overgegaan wordt tot een individuele berekening. De concrete juridische invulling van dit alles blijft echter onduidelijk, net als de manier waarop de certificaten onder de werknemers verdeeld dienen te worden. Mogelijk wil men deze onderwerpen nader regelen via een $\mathrm{AMvB}$, waartoe de gewijzigde versie van het wetsvoorstel de mogelijkheid opent. ${ }^{27}$

24. Zie de consultatiereacties van VNO-NCW, SBI Formaat en Eumedion. Mogelijk kan deze prikkel worden gemitigeerd door gebruik te maken van de wettelijke mogelijkheid kwaliteitseisen aan de aandeelhouder te stellen (art. 2:87b lid 1 en 2:192 lid 1 onder b BW). Bijv. door te bepalen dat de aandelen die onder de wet Eerlijk Delen worden uitgegeven slechts kunnen worden gehouden door de STAK die de vennootschap ingevolge de wet Eerlijk Delen heeft opgericht, dan wel door werknemers in dienst van de vennootschap.

25. In het kader van zeggenschapsrechten kan ook nog kort worden gewezen op het verschil in vergaderrecht tussen NV's en BV's. Waar certificaathouders op grond van art. 2:117 lid 2 BW automatisch vergaderrecht hebben, dient dit bij BV's op grond van art. 2:227 lid 2 BW statutair te worden vastgelegd. Het wetsvoorstel Eerlijk Delen behandelt ook dit onderwerp niet.

26. Zie de consultatiereacties van VNO-NCW, Eumedion, de GCV en SBI Formaat.

27. Kamerstukken II 2020/21, 35672, nr. 3, p. 5-6. Anders dan het oorspronkelijke voorstel voorziet het nieuwe voorstel in de mogelijkheid om nadere regels omtrent de oprichting en doelstelling van de STAK te stellen bij of krachtens AMvB, zie Kamerstukken II 2020/21, 35672, nr. 3, p. 1-2. Kamerstukken II 2020/21, 35672, nr. 3, p. 6 schrijft over de mogelijke onderwerpen die via een dergelijke $\mathrm{AMvB}$ geregeld kunnen worden: 'Hierbij valt onder meer te denken aan regels over de wijze waarop de verdeling van certificaten onder werknemers geschiedt en nadere regels over de tenuitvoerlegging van deze wet door groepsmaatschappijen. 
Indien de Nederlandse wetgever besluit om het wetsvoorstel nader uit te werken, kan de Oostenrijkse wet wellicht als inspiratiebron dienen. Daar is de stichting voor werknemersparticipatie (Mitarbeiterbeteiligungsstiftung) sinds januari 2018 onderdeel van een fiscaal beleid dat werknemersparticipatie op vrijwillige basis moet stimuleren. Ook hier is een $10 \%$-grens aan de zeggenschapsrechten gesteld, en ook hier is het de bedoeling dat de stichting de zeggenschapsrechten die zijn verbonden aan de aandelen uitoefent. De aandelen worden gratis of met korting aan de werknemers overgedragen, die hun aandelen op hun beurt tot het eind van de arbeidsrelatie over dienen te dragen aan de stichting. De stichting neemt deze aandelen vervolgens fiduciair in bewaring en beheer en gaat over tot een uniforme uitoefening van de stemrechten op deze aandelen. Er worden uitdrukkelijk fiscale voordelen gekoppeld aan het onderbrengen van de aandelen in de stichting. Dit blijkt uit het feit dat een deel van deze voordelen voor de werknemer komt te vervallen indien de aandelen tussentijds aan hem of haar worden overgedragen. ${ }^{28}$ Nadere bestudering van deze regeling zou een bron van inspiratie kunnen vormen voor Nederland.

\section{Kanttekeningen bij de toekenning van} zeggenschapsrechten in beide wetsvoorstellen

Wanneer beide wetsvoorstellen tot wet zouden verworden, treedt een soort 'dubbelop'-effect op. De OR krijgt dan over sommige onderwerpen zowel een instemmingsrecht op grond van de WOR als beslissingsmacht via de zeggenschapsrechten die zijn gekoppeld aan de aandelen die de door de OR bestuurde STAK houdt. Voor NV's geldt dit meer dan voor BV's, omdat artikel 2:107a BW voor NV's voorschrijft dat besluiten van het bestuur omtrent een belangrijke verandering in de identiteit of het karakter van de vennootschap aan goedkeuring van de AV zijn onderworpen. Wanneer het gaat om de benoeming, schorsing of het ontslag van een bestuurder of commissaris van een NV, levert de combinatie van medezeggenschap en aandeelhouderschap de situatie op dat de OR zowel voorafgaand aan de algemene vergadering een standpunt kan bepalen, als een stem kan uitbrengen tijdens deze vergadering. ${ }^{29}$ Daarnaast geldt voor beide rechtsvormen dat met $5 \%$ van de aandelen kan worden afgedwongen dat een besluit tot fusie of splitsing door de AV wordt genomen en niet door het bestuur. ${ }^{30}$ Indien de OR van mening is dat de

28. Informatie omtrent deze regeling is ontleend aan de Oostenrijkse $\mathrm{KvK}$ website: www.wko.at/service/steuern/Steuerliche_Foerderung_der_Mit arbeiterbeteiligung.html en F.R. Walter, Perspektiven der Mitarbeiterkapitalbeteiligung, Zeitschrift für Rechtspolitik 2019/227. Uitkeringen op deze aandelen zijn tot EUR 4500 per jaar vrijgesteld van belastingen. De fiscale voordelen die gekoppeld zijn aan deze aandelen zijn groter als de aandelen via een medezeggenschapsstichting worden gehouden. In dit kader valt op de KvK-website te lezen: 'Die Aktien (inklusive damit verbundene Stimmrechte) müssen bis zum Ende des Dienstverhältnisse auf eine Mitarbeiterbeteiligungsstiftung zur treuhändischen Verwah rung und Verwaltung übertragen werden. (...) Werden Aktien vor Beendigung des Dienstverhältnisses an den Mitarbeiter übergeben, ist dies ein Vorteil aus dem Dienstverhältnis und es kommt zur Nachbesteuerung.'

29. Art. 2:134a en 2:144a BW.

30. Art. 2:331 lid 3 en 2:334ff lid 3 BW. strategische beslissingen van het bestuur echt niet door de beugel kunnen, kan hij bovendien als bestuur van de STAK op basis van het aandelenbezit gebruik maken van het enquêterecht en een onderzoek naar het beleid en de gang van zaken van de vennootschap verzoeken. Met $1 \%$ aandelenbezit kan reeds een enquête worden verzocht in een vennootschap met een geplaatst kapitaal van meer dan EUR 22,5 miljoen. Voor vennootschappen met een lager geplaatst kapitaal geldt dat deze grens bij $10 \%$ ligt. ${ }^{31}$ Beide dus binnen bereik voor de vennootschappen waar het wetsvoorstel Eerlijk Delen op ziet. ${ }^{32}$ Tot slot merk ik op dat wat betreft het bezoldigingsbeleid geldt dat de AV dit reeds vaststelt, en dat de OR van NV's reeds in de gelegenheid wordt gesteld om zijn standpunt over dit beleid te bepalen voorafgaand aan de vergadering. ${ }^{33}$ Voor beursgenoteerde BV's/NV's geldt dat zij dit beleid elke vier jaar ter goedkeuring dienen voor te leggen aan de AV, en dat de OR in de gelegenheid is gesteld hierover advies uit te brengen. ${ }^{34}$ De vereiste meerderheid ter vergadering is in die gevallen drie vierde van de uitgebrachte stemmen (tenzij de statuten een lagere meerderheid voorschrijven), zodat een $10 \%$-werknemersaandeel significante en mogelijkerwijs doorslaggevende invloed kan uitoefenen.

Naast het 'dubbelop'-effect geeft een instemmingsrecht op grond van het wetsvoorstel Eerlijk Beslissen over de zojuist omschreven besluiten een ander type recht dan een zeggenschapsrecht via aandelenbezit. Wanneer het bestuur een besluit neemt dat onder artikel 2:107a BW valt, tast het ontbreken van goedkeuring van de AV de vertegenwoordigingsbevoegdheid van het bestuur niet aan op grond van lid 2 van dat artikel. Echter, wanneer dergelijke besluiten onder het instemmingsrecht van de WOR gaan vallen, wordt een recht gecreëerd dat kan zorgen voor het doorschuiven van de hete aardappel naar de rechter. Artikel 27 lid 4 WOR bepaalt immers dat een ondernemer die geen instemming van de $O R$ heeft verkregen voor een voorgenomen besluit, bij de kantonrechter toestemming kan vragen om het besluit alsnog te nemen. Deze remedie verschilt wezenlijk van de remedie die de wetgever heeft bedacht ten aanzien van adviesplichtige besluiten. Op grond van artikel 26 WOR ligt het initiatief voor de rechtsgang bij een besluit dat afwijkt van het door de OR gegeven advies niet bij de ondernemer, maar bij de OR. Bovendien kan dit beroep uitsluitend worden ingesteld ter zake dat de ondernemer bij afweging van de belangen niet in redelijkheid tot zijn besluit had kunnen komen. Bij het

31. Art. 2:346 lid 1 onder b en c BW.

32. Vgl. in dit kader de consultatiereactie van Marnix Holtzer, die erop wijst dat de toekenning van de enquêtebevoegdheid aan de OR bij de laatste herziening van het enquêterecht per 1 januari 2013 een dusdanig hevig omstreden punt was dat dit niet tot een wettelijke bevoegdheid voor de OR heeft geleid.

33. Art. 2:135 lid 1 en 2 en 2:245 lid 1 BW. Bij BV's is de AV als hoofdregel bevoegd, maar mogen de statuten een afwijkende regeling bevatten.

34. Art. 2:135a lid 2 en 3 BW. Via de schakelbepaling van art. 2:187 BW geldt art. 2:135a BW ook voor de beursgenoteerde BV. Zie over de recente wetswijzigingen omtrent het bezoldigingsbeleid E.C.H.J. Lokin, Implementatie van de herziene Aandeelhoudersrichtlijn: het bezoldigingsbeleid, Ondernemingsrecht 2019/159. 


\section{Maandblad}

Ondernemingsrecht

instemmingsrecht is de situatie omgekeerd en ligt het initiatief bij de ondernemer. Ook de rechterlijke toetsingsnorm verschilt in een dergelijk geval. De kantonrechter geeft slechts toestemming indien de beslissing van de ondernemingsraad om geen instemming te geven onredelijk is, of het voorgenomen besluit van de ondernemer gevergd wordt door zwaarwegende bedrijfsorganisatorische, bedrijfseconomische of bedrijfssociale redenen'. De rechter dient dan een tweeledige toets uit te voeren, te beginnen met een redelijkheidstoets waarbij de argumenten van de ondernemer voor zijn voorgenomen besluit worden afgewogen tegen de argumenten van de OR om instemming te onthouden. Pas als deze argumenten even zwaar wegen, komt de rechter toe aan het tweede deel van de toets. Dit deel van de toets houdt in dat geen goedkeuring zal worden verleend, tenzij de ondernemer kan aantonen dat er zwaarwegende bedrijfsorganisatorische, bedrijfseconomische of bedrijfssociale redenen zijn die tot goedkeuring zouden moeten leiden (de zwaarwegende-redenentoets). ${ }^{35}$ Wat betreft besluiten van strategische aard zal de rechter dus een bijzonder toetsingskader ter hand moeten nemen, dat momenteel is toegesneden op de beperkte instemmingsrechten die de wet kent. De toetsingsnorm van artikel 27 lid 4 WOR dwingt de rechter daarbij in een mal, waarin een zorgvuldige afweging van belangen dient plaats te vinden en bij gelijke weging het voordeel bij de OR ligt. De OR krijgt hiermee een recht in handen dat aanvoelt als een vetorecht, dat niet alleen beperkend werkt op de beleidsvrijheid van het bestuur, maar ook traagheid in de besluitvorming kan veroorzaken. Holtzer kwalificeert het toekennen van de instemmingsrechten in de wet Eerlijk Beslissen zelfs als een onaanvaardbare doorbreking van de huidige vennootschappelijke verhoudingen in Nederland. Uit de ABN AMRO-uitspraak volgt immers dat het bepalen van de strategie van de vennootschap en de daarmee verbonden onderneming in beginsel een aangelegenheid is van het bestuur van de vennootschap, dat de raad van commissarissen ( $\mathrm{RvC}$ ) daarop toezicht houdt en dat de AV haar opvattingen hierover tot uitdrukking kan brengen via de uitoefening van de aan haar in wet en statuten toegekende rechten. Een instemmingsrecht van het medezeggenschapsorgaan dat voorafgaat aan strategische besluitvorming door het bestuur past niet in deze bevoegdheidsverdeling, en doet afbreuk aan de bestuursautonomie die de grondslag van ons huidige ondernemingsrecht vormt, aldus Holtzer. ${ }^{36}$

\section{Het kernidee achter de wetten in historisch perspectief}

Los van de vele juridische discussies en praktische vragen over de houdbaarheid van de voorgestelde regelingen, is het de moeite waard om de wetsvoorstellen tegen de achtergrond van de geschiedenis te plaatsen. De ideeën achter de 'eerlijke economie' waar de wetsvoorstellen op zien, zijn (uiteraard) niet

35. A. Briejer, Vervangende toestemming: de dubbele toetsingsnorm ex art. 27 lid 4 WOR toegepast, A\&O 2019, p. 27.

36. Consultatiereactie Marnix Holtzer, onder verwijzing naar HR 13 juli 2007, ECLI:NL:HR:2007:BA7970, JOR 2007/178 m.nt. Nieuwe Weme (ABN AMRO). nieuw. Het gaat om de als te scheef gepercipieerde verhouding tussen kapitaal en arbeid, die moet worden gecorrigeerd via financiële beloning en zeggenschap voor werknemers. Het beeld dat uit de hiernavolgende historische schets naar voren komt, is dat van een slingerbeweging. Aan de start van de industriële revolutie was de invloed van de factor arbeid nog marginaal, maar diens positie groeide en bereikte een hoogtepunt in de jaren zeventig van de vorige eeuw. Belangrijk is dat men toen naast zeggenschap genoegen nam met een lager loon, mits daar voldoende sociale voorzieningen tegenover stonden. Zo kon een laag loonpeil, gebaseerd op een bestaansminimum, worden gecompenseerd door een grotere bestaanszekerheid via wetten zoals de AOW, WAO en de Algemene Bijstandswet. ${ }^{37}$ In de decennia die op de jaren zeventig volgden, zette voor werknemers langzaamaan het verval in, zowel op het gebied van medezeggenschap als op het gebied van beloning.

Een van de eerste ondernemers van Nederland die actie ondernam op het terrein van winstdeling en medezeggenschap was Van Marken. Als directeur (tevens minderheidsaandeelhouder) van de in 1869 opgerichte Nederlandse Gist \& Spiritus Fabriek NV (voorloper van het huidige DSM, hierna: de Gistfabriek) voerde hij een stelsel van winstdeling en een rudimentaire vorm van medezeggenschap bij zijn onderneming in via een personeelsvertegenwoordiging, genaamd 'de Kern'. Het doel van de medezeggenschap was het bevorderen van de welvaart van het personeel en het welslagen van de onderneming door onderlinge overleggen tussen bestuur en vertegenwoordigers van het personeel. ${ }^{38}$ Het was daarbij uitdrukkelijk niet de bedoeling dat werknemers zich met het ondernemingsbeleid bemoeiden. ${ }^{39}$ De lonen bij de Gistfabriek werden vastgesteld door de directie, onder goedkeuring van commissarissen en na het personeel 'desverlangend daaromtrent te hebben gehoord'. ${ }^{40}$ Tien procent van de overwinst werd bovendien ter beschikking gesteld van het bestuur en commissarissen, om te gebruiken in het belang van het personeel, wederom na hen daar desverlangend over te hebben gehoord. ${ }^{41}$ Werknemers deelden voorts mee in de winsten van het bedrijf en zelfs in het

37. K.E. Sluyterman, Kerende kansen. Het Nederlandse bedrijfsleven in de twintigste eeuw, Amsterdam: Boom 2003, p. 189-190 en E. Nijhof \& A. van den Berg, Het menselijk kapitaal. Sociaal ondernemersbeleid in Nederland (BINT-reeks, nr. 4), Amsterdam: Boom 2012, p. 62.

38. J.J.M. van Mierlo, Medezeggenschap en de spanning tussen WOR en ondernemingsrecht (VDHI nr. 117; diss. Nijmegen), Deventer: Kluwer 2013, p. 29-30. De Kern had initieel een uitsluitend raadgevend karakter, later kwam daar het 'recht van beslissing' bij inzake voorstellen die uitsluitend de belangen van het personeel raakten.

39. Nijhof \& Van den Berg 2012, p. 181. Bovendien was geen sprake van een groot democratisch gehalte, aangezien de helft van de leden van de Kern door de directie werd aangewezen. Het betrof personen die hun trouw aan de onderneming hadden bewezen door hun anciënniteit.

40. Van Mierlo 2013, p. 30.

41. Van Mierlo 2013, p. 30. 
kapitaal van de onderneming via certificaten van aandelen. ${ }^{42}$ Van Marken was met zijn initiatieven de eerste Nederlandse ondernemer die winstdeling in zijn onderneming invoerde, en kreeg hier destijds zelfs internationaal bekendheid mee. ${ }^{43} \mathrm{Hij}$ geloofde dat economische voortuitgang gebaseerd was op samenwerking van de factoren arbeid en kapitaal, niet op een polarisatie daarvan. ${ }^{44}$

Van Marken kreeg initieel wel enige navolging van ondernemende tijdgenoten, zoals D.W. Stork (firmant van de in 1865 opgerichte Machinefabriek Gebroeders Stork \& Co, voorloper van het huidige Stork), maar bleef toch vooral een buitenbeentje. Achter deze kleine groep prominente sociale ondernemers vormden zich vooral vanaf 1880 groepen ondernemers die soortgelijke - maar minder uitgebreide en spectaculaire voorzieningen aan hun personeel begonnen aan te bieden. $\mathrm{Zij}$ volgden het voorbeeld van Van Marken en Stork door fondsen voor zieke, invalide en oudere werknemers op te richten, zorg te dragen voor de gezondheid van hun werknemers of een stelsel van winstdeling in te stellen, al dan niet met het doel dat de werknemers na verloop van tijd eigenaar van 'de zaak' konden worden. Net als bij Van Marken werden daarbij opbrengsten uit de winstdeling ingezet om deze sociale initiatieven en fondsen te bekostigen. Daarnaast werden de fondsen bekostigd uit verplichte bijdragen van arbeiders. Keerzijde hiervan was dat de inkomsten voor deze fondsen terugliepen op die momenten dat zij het hardst nodig waren voor de arbeiders. Wanneer een toenemend aantal arbeiders een beroep op het fonds deed, moesten de bijdragen immers worden verdeeld over een grotere groep, terwijl zij werden opgebracht door het resterende (geslonken) deel van de arbeiders. Ook werden de bijdragen die afhankelijk waren van de bedrijfswinst stopgezet wanneer deze winst terugliep, en in plaats daarvan gebruikt voor het veiligstellen van het voortbestaan van de onderneming. ${ }^{45}$ Rond het begin van de twintigste eeuw werd dan ook duidelijk dat wettelijk ingrijpen van de overheid geboden was om een werkelijk effectieve bestrijding van de financiële risico's van arbeiders teweeg te brengen. ${ }^{46}$ Vanaf het begin van de twintigste eeuw kwamen er vele wetten die beoogden werknemers te beschermen tegen hun economisch zwakke positie, waaronder wetten op het gebied van sociale

42. Voor een uitgebreide opsomming van deze en andere sociale instellingen van Van Marken ter verbetering van de positie van werknemers, zie H.C. Kleij, Sociaal ondernemerschap. Een rechtssociologische studie van de antwoorden van J.C. van Marken Jr. op de Sociale Kwestie (diss. Utrecht), 1986, p. 78-81 en 118.

43. G.F. Evelein, Industrial welfare work in Holland, De NV 1922 , p. 214-215.

44. Kleij 1986, p. 70 duidt dit standpunt van Van Marken aan als 'Derde Weg' in het conflict tussen kapitaal en arbeid, waarbij Marx de eerste weg genoemd kan worden en het katholieke corporatisme de tweede.

45. Nijhof \& Van den Berg 2012, p. 48.

46. Nijhof \& Van den Berg 2012, p. 48 zekerheid. ${ }^{47}$ Zo werden de vrijwillige initiatieven van werkgevers om werknemers tegen financiële risico's te beschermen vervangen door regels van dwingend recht.

Begin twintigste eeuw ontstond ook maatschappelijke discussie omtrent de wenselijkheid van (mede)zeggenschap van werknemers binnen de onderneming. Deze discussie kwam voort uit de toenemende mondigheid van de arbeider, en tevens de toenemende invloed van de vakbeweging. Om de vakbonden zo veel mogelijk buiten de deur te houden en grip op hun personeel te behouden, stelden veel ondernemers hun eigen personeelsvertegenwoordigingen (kernen) in. De opkomst van de vakbeweging stimuleerde zo de opkomst van medezeggenschap in ondernemingen. ${ }^{48}$ Tijdens de Duitse bezetting bleef dit 'kernwezen' bestaan, ondanks pogingen van de bezetter om dit de kop in te drukken door vakbonden te verbieden en het Nationaal Arbeidsfront (NAF) in te stellen als de vertegenwoordiging van het personeel. De voormannen van het NAF kregen in Nederland echter geen voet aan de grond. Het kernwezen bleef bestaan en breidde zich zelfs uit vanwege de grote behoefte aan overleg ten gevolge van de maatregelen van de bezetter. ${ }^{49}$

'De problemen van de depressiejaren en de ontberingen tijdens de bezettingsjaren drukten de belangentegenstellingen tussen werknemers en werkgevers naar de achtergrond en makten plaats voor een klimaat waarin na de Tweede Wereldoorlog naar samenwerking werd gestreefd om tot wederopbouw te kunnen komen. ${ }^{50}$

Vrijwel direct na de Tweede Wereldoorlog, op 17 mei 1945, werd als 'het symbool van het historische compromis tussen arbeid en kapitaal' de Stichting voor de Arbeid opgericht. ${ }^{51}$ Dit was een permanent orgaan van overleg tussen de bestuurders van de centrale werkgevers- en arbeidersorganisa-

47. Herziening van het ondernemingsrecht; rapport van de commissie o.l.v. P.J. Verdam, Den Haag: Staatsuitgeverij 1967, p. 12 en I.J. Brugmans, Paardenkracht en mensenmacht. Sociaal-economische geschiedenis van Nederland, Den Haag: Martinus Nijhoff 1976, p. 408-412. Jansen 2020, p. 1512. Het ging o.a. om wetten op het gebied van arbeidscontractvoorwaarden, cao's, sociale zekerheid en arbeidsomstandigheden.

48. Nijhof \& Van den Berg 2012, p. 182-183. De vakbonden op hun beurt waren hier niet van gecharmeerd en besloten initieel tot een boycot van het kernwezen. Na het uitbreken van de Eerste Wereldoorlog kregen de vakbonden geleidelijk aan meer invloed en realiseerden zij zich dat het kernwezen een bondgenoot kon zijn en als verlengstuk van de vakbeweging kon dienen. Zij schrijven bijv. hoe de cao's, die in toenemende mate werden afgesloten, wel goed primaire arbeidsvoorwaarden konden vastleggen, maar dat het vastleggen van secundaire arbeidsvoorwaarden maatwerk vereiste. Hier konden de kernen waardevolle diensten bewijzen.

49. Nijhof \& Van den Berg 2012, p. 189.

50. Nijhof \& Van den Berg 2012, p. 189.

51. J.L. van Zanden, Een klein land in de 20e eeuw. Economische geschiedenis van Nederland 1914-1995, Utrecht: Het Spectrum 1997, p. 182. De snelle oprichting was mogelijk omdat de belangrijkste kopstukken uit de - tijdens de bezetting opgeheven - vakcentrales en werkgeversorganisaties in het geheim overleggen waren blijven voeren over de sociale politiek na de oorlog. Men zegt ook wel dat het corporatisme werd geïnstitutionaliseerd in de Stichting van de Arbeid in 1945 en de SociaalEconomische Raad (SER) in 1950. 


\section{Maandblad}

Ondernemingsrecht

ties en verschafte werknemers medezeggenschap op macroniveau. ${ }^{52}$ De factor arbeid kreeg een cruciale rol in de maatschappelijke discussies over de wederopbouw van het land en het inrichten van de economische structuren in een tijd waarin naar een middenweg werd gezocht tussen het kapitalisme en het socialisme. Men was het erover eens dat het stelsel van economische productie gepaard diende te gaan met een sociaal gezicht en een actieve overheid. ${ }^{53}$ Ook op mesoniveau ontstond een vorm van medezeggenschap voor werknemers. Via de Wet op de Publiekrechtelijke Bedrijfsorganisatie konden product- of bedrijfschappen worden opgericht voor specifieke sectoren of productiekolommen in het bedrijfsleven, die met overheidsgezag waren bekleed. Het bestuur van dergelijke bedrijfslichamen werd gevormd door vertegenwoordigers van de betrokken werkgevers- en werknemersorganisaties. ${ }^{54}$ Overigens merkt Jacobs op dat het systeem van de publiekrechtelijke bedrijfsorganisatie (PBO) nooit echt goed van de grond is gekomen. ${ }^{55}$

Op microniveau werd de gedachte dat de individuele onderneming onderdeel uitmaakt van de maatschappij steeds meer gemeengoed, evenals de gedachte dat het een democratische eis is dat de werknemer binnen de onderneming inspraak moet hebben op het beleid. ${ }^{56}$ De OR ontwikkelde zich van een orgaan van overleg, dat zijn taak op grond van artikel 6 lid 1 WOR 1950 uitoefende 'onder erkenning van de zelfstandige functie van de ondernemer', naar een orgaan waarvan de bestuurder niet langer onderdeel uitmaakte. In plaats daarvan diende de bestuurder op grond van artikel 23 WOR in regelmatig overleg te treden met de OR in de overlegvergadering. Van Mierlo schrijft dat de medezeggenschap in 1979 'een volwassen karakter' had gekregen:

'In tijd zien we tussen 1950 en 1979 de volgende ontwikkeling: de wetgever beschouwde de ondernemingsraad in 1950 nog als een orgaan van samenwerking tussen leiding

52. J.J.M. Veraart, Wezen en doel van de Stichting van den Arbeid, De NV 1947, p. 15-16. Vgl. Nijhof \& Van den Berg 2012, p. 190-191.

53. K. Sluyterman \& B. Wubs, Over grenzen. Multinationals en de Nederlandse markteconomie (BINT-reeks, nr. 2), Amsterdam: Boom 2009, p. 155. G. Westerhuis \& A. de Jong, Over geld en macht. Financiering en corporate governance van het Nederlandse bedrijfsleven (BINT-reeks, nr. 7), Amsterdam: Boom 2015, p. 112 spreken van een gemengde economie die zich tussen een kapitalistisch en socialistisch model bevond.

54. R. Guldenmund, De levensbeschouwelijke wortels van de publiekrechtelijke bedrijfsorganisatie, TvRRB 2012, p. 74-75. Product- en bedrijfschappen waren bijv. bevoegd om algemeen verbindende voorschriften (verordeningen) vast te stellen en heffingen op te leggen voor die bedrijven waarvoor zij waren opgericht. De uitoefening van een bepaalde economische activiteit bepaalde of een persoon of bedrijf onder de werking van een product- of bedrijfschap viel. De product- en bedrijfschappen stonden onder toezicht van de SER, het Ministerie van Sociale Zaken en Werkgelegenheid en het Ministerie van Economische Zaken, Landbouw en Innovatie.

55. A.T.J.M. Jacobs, Collectief arbeidsrecht (MSR nr. 28), Deventer: Wolters Kluwer 2017/3.2 (p. 34-35).

56. P.F. van der Heijden, Medezeggenschap, een inleiding, in: P.F. van der Heijden (red.), Schets van het Medezeggenschapsrecht, Deventer: Kluwer 1992, p. 3. en werknemers, in 1971 werd de raad een orgaan waarbinnen overleg tussen leiding en vertegenwoordigers van werknemers plaats vond, vanaf 1979 is de raad nog slechts een orgaan dat werknemers vertegenwoordigt en in die hoedanigheid een wezenlijke functie vervult bij het overleg met de ondernemingsleiding. ${ }^{57}$

Naast de verschillende ontwikkelingen op het gebied van medezeggenschap, werd ook de structuurregeling in 1971 ingevoerd. Hierdoor kreeg zowel de factor arbeid (OR) als de factor kapitaal (de AV of een door de AV ingestelde commissie van aandeelhouders) in structuurvennootschappen het recht om bezwaar te maken tegen de voordracht van een nieuwe commissaris door de zittende $\mathrm{RvC}^{58}$

Opvallend is dat het loon van werknemers met de formele versterking van hun positie binnen de vennootschap geen vlucht nam in de jaren na de Tweede Wereldoorlog, waardoor Nederland in West-Europa zelfs bekend kwam te staan als een lagelonenland. Dit kwam door een regeringsbeleid dat was gericht op lage lonen ten gunste van de exportpositie, waarbij lonen werden gekoppeld aan een minimumlevenspeil (geleide loonpolitiek). Werknemers gingen akkoord met een lager loon, maar daartegenover stond dat zij in perioden dat dit loon niet toereikend zou zijn (ziekte, ouderdom, werkloosheid), zouden worden opgevangen door een groot sociaal vangnet. ${ }^{59}$ Nijhof en Van den Berg schrijven:

'Zonder deze belofte zou het voor de vakbeweging veel moeilijker, zo niet onmogelijk zijn geweest de achterban te winnen voor loyale medewerking aan de geleide loonpolitiek.' 60

Ondertussen was bij ondernemers het winstbegrip meegeëvolueerd met de ontwikkelingen in het sociaal en economisch denken dat zich in de twintigste eeuw had voorgedaan. Sluyterman omschrijft hoe ondernemingen minder de nadruk legden op het maken van winst, maar met name op het veiligstellen van de continuiteit van de onderneming omdat kapitaalsintensieve projecten pas op langere termijn inkomsten opleverden, en ook omdat zo een blijvende band met het personeel opgebouwd kon worden. Deze band werd vooral via secundai-

57. Van Mierlo 2013, p. 43. Op p. 44 kwalificeert hij dit als een 'volwassen karakter'.

58. Art. 52h WvK 1971, Kamerstukken II 1969/70, 10751, nr. 3 (MvT) Art. 52c WvK 1971 bepaalde dat aan drie voorwaarden moest worden voldaan om als grote vennootschap te kwalificeren: (1) de vennootschap diende een geplaatst kapitaal (incl. reserves volgens de balans met toelichting) van minstens NLG 10 miljoen te hebben; (2) de vennootschap of een afhankelijke maatschappij moest een krachtens wettelijke verplichting ingestelde OR hebben; en (3) bij de vennootschap en haar afhankelijke maatschappijen tezamen dienden ten minste honderd arbeiders werkzaam te zijn.

59. Nijhof \& Van den Berg 2012, p. 61 en 63.

60. Nijhof \& Van den Berg 2012, p. 63. Vanaf 1964 konden de lonen niet langer laag worden gehouden vanwege de krapte op de arbeidsmarkt. Gedurende tien jaar vond dan ook een 'ontploffing' van de lonen plaats. CBS, Terugblikken. Een eeuw in statistieken, Den Haag/Heerlen: CBS 2010, p. 30-31. 
re arbeidsvoorwaarden bereikt, en niet zozeer via winstdeling. ${ }^{61}$ Dit past zodoende in een tijd waarin de samenleving als een soort stilzwijgend 'sociaal contract' met elkaar had afgesproken dat een lager loon zou worden uitgewisseld tegen sociale voorzieningen. Uit een toespraak van een functionaris van Unilever blijkt dat dit verantwoordelijkheidsbesef tegenover de werknemers en tegenover het algemeen belang diepgeworteld was. Hij schreef over het grootbedrijf:

'In toenemende mate zal het handelingen moeten verrichten die strijdig schijnen met het eigenbelang, althans op korte termijn. Want op de lange duur zal blijken dat het eigenbelang niet meer los gezien kan worden van het algemeen belang. (...) Is het grootbedrijf bevreesd voor nog verder strekkende overheidsbemoeiing in de toekomst, dan is er slechts één weg: zó werken, zó besturen dat men die overheid als het ware de wind uit de zeilen neemt. Daartoe is het besef vereist dat het doen - maar evenzeer het laten - van de grote onderneming in vele opzichten zijn weerslag heeft op het gehele volksbestel.' ${ }^{62}$

$\mathrm{Na}$ deze jaren waarin bestuurders zich corporate statesmen waanden, en aandeelhouders als bijzaak werden beschouwd, volgden de jaren zeventig en tachtig. In deze jaren sloeg de naoorlogse samenwerking tussen overheid en bedrijfsleven om in onderlinge confrontatie en vijandigheid als gevolg van de 'antikapitalistische stemming' die onder de bevolking heerste en de door het bedrijfsleven als te links gepercipieerde agenda van Den Uyl. ${ }^{63}$ Niet lang daarna volgden economische recessies, onder meer als gevolg van de wereldwijde oliecrises. Toen de overheid er niet in slaagde om deze recessies adequaat te lijf te gaan, wonnen de ideeën van Milton Friedman aan populariteit. Friedman pleitte voor een kleine overheid en zo veel mogelijk vrijemarktwerking met zo min mogelijk belemmeringen. ${ }^{64}$ In Nederland kreeg deze denkwijze in de jaren tachtig vorm in het terugdringen van overheidsuitgaven om 'de crisis van de verzorgingsstaat' te lijf te gaan. Het vertrouwen in de overheid als economisch fundament werd met deze koerswijziging vervangen door een vertrouwen in de markt en sociale voorzieningen werden afgebouwd. ${ }^{65}$

Niet lang daarna zou de aandeelhouder worden gezien als belangrijk(st)e stakeholder van de onderneming als gevolg van

61. K.E. Sluyterman, Gedeelde zorg. Maatschappelijke verantwoordelijkheid van ondernemingen in historisch perspectief (oratie Utrecht), Utrecht: Universiteit Utrecht, Faculteit der Letteren 2004, p. 12-13. Illustratief voor de ondernemersgeest is voorts J. Bartels, De ondernemer en zijn taak (rede ter gelegenheid van de conferentie van de Federatie van Junior-Kamers in Nederland te Utrecht op 10 november 1962), Rotterdam: Unilever NV 1963.

62. P. Rijkens, Het grootbedrijf in ontwikkeling, De Gids (124) 1961, p. 346.

63. Nijhof \& Van den Berg 2012, p. 65.

64. M. Friedman, Capitalism and freedom (40th anniversary edition with a new preface by the author), Chicago/Londen: The University of Chicago Press 1962 (2002).

65. J. Paulussen \& I. Blanken, Samenwerking tusschen Nederlandse industrieën met groote internationale belangen: 70 jaar contactcommissie (1934-2004), Zaltbommel: Uitgeverij Aprilis 2004, p. 111. de populariteit van de agency-theorie, die was ontwikkeld aan de Chicago School, waar Milton Friedman aan was verbonden. Dit gedachtegoed, waarin aandeelhouders worden beschouwd als de eigenaren van de onderneming en het bestuur als hun lasthebber, kreeg grip op de samenleving in de jaren negentig en het eerste decennium van de 21 ste eeuw, net als het inmiddels beroemde adagium dat wordt gekoppeld aan Friedman: 'The social responsibility of business is to increase its profits. ${ }^{66}$ Hoewel aandeelhouders juridisch niet als eigenaren kunnen worden gekwalificeerd in Nederland, kreeg deze economische benadering eind twintigste eeuw ook grip op het Nederlandse ondernemingsrecht, zoals uitgebreid omschreven door Overkleeft. ${ }^{67}$ In 2004 werd de hernieuwde aandacht voor de aandeelhouder geformaliseerd door het wijzigen van de structuurregeling in het voordeel van de aandeelhouder. Waar de structuurregeling van 1971 had gedraaid om de gelijkheid van de factoren arbeid en kapitaal, ging het ditmaal om het 'teruggeven' van bevoegdheden aan de aandeelhouder. ${ }^{68}$ Dit betreft met name de bevoegdheid om de $\mathrm{RvC}$ te benoemen en te ontslaan. ${ }^{69}$ Kandidaten worden voorgedragen door de $\mathrm{RvC}$, eventueel op aanbevelen van de AV en de OR (die tevens over een versterkt (niet-bindend) aanbevelingsrecht beschikt voor een derde van de leden van de $\mathrm{RvC}$ ). ${ }^{70}$ De AV kan de kandidaat-voordrachten van de $\mathrm{RvC}$ of $\mathrm{OR}$ echter afwijzen. ${ }^{71}$

Om de belangen van bestuurders en topmanagers gelijk te laten lopen met die van aandeelhouders werden optieregelingen in de jaren negentig populair. Werknemersaandelen voor het management stonden in dit kader dan ook volop in de aandacht. De tijdsgeest van deze jaren wordt als volgt samengevat door Sluyterman:

'Deregulering en privatisering gingen hand in hand met toenemende globalisering. De economische hausse na 1991 leek het gelijk van het vrije kapitalisme te bevestigen. De stijgende winstgevendheid in het bedrijfsleven werd niet aangewend om alsnog het democratiseringsideaal van de jaren zeventig te realiseren. In plaats daarvan werden optieregelingen gë̈ntroduceerd die werknemers een flexibele beloning gaven en hen stimuleerden om aandeelhouders te worden van de onderneming waarin zij werkten. Maar niet voor alle werknemers was een plaats gedekt aan de tafel. Stijgende beurskoersen en riante optieregelin-

66. Dit was de titel van een ingezonden artikel van Milton Friedman aan The New York Times, dat werd gepubliceerd op 13 september 1970.

67. F.G.K. Overkleeft, De positie van aandeelhouders in beursvennootschappen (diss. Rotterdam), Deventer: Wolters Kluwer 2017, p. 147-213.

68. H. van Roosmalen \& H. Koster, Vennootschappelijke medezeggenschap onder druk. Sluit de structuurregeling nog aan op de economische werkelijkheid?, O\&F (27) 2019, afl. 1, p. 18. Het SER-advies 'Het functioneren en de toekomst van de structuurregeling' uit 2001, p. 82 sprak over de 'teruggave' aan de AV van bevoegdheden die haar door de structuurregeling zijn ontnomen.

69. Art. 2:158/268 lid 4 en $2: 161 \mathrm{a} / 271 \mathrm{a}$ BW.

70. Art. 2:258/268 lid 4-6 BW.

71. Art. $2: 158 / 268$ lid 6 en 9 BW. 
gen voor topmanagers gingen gepaard met reorganisaties. $^{72}$

Optie- en aandelenregelingen kwamen vooral voor onder managers en stafleden bij beursgenoteerde bedrijven (hier is immers een markt en de prijs is bekend). ${ }^{73}$ Dit past bij de trend in de jaren negentig waarbij het bestuur als steeds belangrijker deel van hun salarispakket een variabele beloning in de vorm van opties, aandelen of bonussen kreeg uitgekeerd. ${ }^{74}$ Op Europees niveau ontstond in deze tijd een bredere aandacht voor werknemersaandelen voor alle werknemers. Er werden kort na elkaar meerdere onderzoeken naar de 'Promotion of Participation by Employed Persons in Profits and Enterprise Results' uitgevoerd (de PEPPER-studies). ${ }^{75}$ Ondertussen kwam de Raad van de Europese Gemeenschappen met een aanbeveling voor de bevordering van werknemersparticipatie in bedrijfswinsten en -resultaten, inclusief aandelenparticipatie. Daarin werd overwogen dat 'de aanmoediging van financiële bedrijfsparticipatie van werknemers (...) kan worden beschouwd als een manier om een verderreikende verdeling te verkrijgen van het vermogen van ondernemingen, dat mede door de werknemers is gevormd'. ${ }^{76}$ Ook Nederlandse vakbonden pleitten begin deze eeuw voor werknemersaandelen, maar dan vooral voor alle werknemers en niet een selecte groep. In 2000 wilde de FNV dat de modale werknemer wordt beloond met aandelen en opties, ${ }^{77}$ en in 2008 pleitte ook de CNV Dienstenbond voor participatieaandelen voor werknemers van beursgenoteerde bedrijven. De participatieaandelen zouden moeten worden gehouden door een speciaal op te richten College van Werknemers en zouden dividendloos moeten zijn. Het doel van deze aandelen was het verkrijgen van invloed van het personeel op de onderneming, dat wil zeggen 'een stem bij belangrijke beslissingen en zelfs een vetomacht tijdens aandeelhoudersvergaderingen'. ${ }^{78}$ Dit was volgens de CNV noodzakelijk omdat de kredietcrisis had laten zien waartoe het najagen van kortetermijnwinsten kon leiden. Via deze maatregel konden langetermijndenken en de continuïteit van het bedrijf weer leidend worden. De hier besproken Europese en vakbondsinitiatieven vonden echter geen brede weerklank bij ondernemingen.

Een mogelijke verklaring voor het weinig voorkomen van PEPPER-regelingen in Nederland werd door Poutsma en De

72. Sluyterman 2004, p. 18-19.

73. Poutsma, Mol \& Van Beusekom 1998, p. 190-192 en 196-197.

74. E.C.H.J. Lokin, De bezoldiging van bestuurders van beursgenoteerde vennootschappen (diss. Rotterdam), Deventer: Wolters Kluwer 2018, p. 88-89.

75. De links naar de vier rapporten zijn online raadpleegbaar via www.eurofound.europa.eu/areas/participationatwork/pepperreports.

76. Aanbeveling 92/443/EEG van de Raad van 27 juli 1992 betreffende de bevordering van werknemersparticipatie in bedrijfswinsten en -resultaten (inclusief aandelenparticipatie) (PbEU 1992, L 245/53).

77. Genoemd in R.M. Beltzer \& R.H. van het Kaar, Werknemersparticipatie in drievoud. De som der delen, Den Haag: Sdu Uitgevers 2001, p. 5 en Voor werknemersaandelen is een 'interne beursgang' nodig, FD 14 augustus 2000.

78. CNV-bond pleit voor werknemersaandelen, ANP 23 oktober 2008.
Nijs in 1998 gezocht in het gegeven dat de institutionele medezeggenschap hier zo goed geregeld was. ${ }^{79} \mathrm{Zij}$ constateerden dat in landen waar het sociaaleconomische stelsel tot het zogenaamde Rijnlandse model gerekend kan worden (zoals Nederland, Duitsland en Zweden), amper sprake is van financiële participatie, terwijl in landen die gekenmerkt worden door antagonistische en oppositionele verhoudingen en weinig institutionele medezeggenschap (zoals het Verenigd Koninkrijk en de Verenigde Staten) juist sprake is van veel mogelijkheden op het vlak van financiële participatie. ${ }^{80}$

'Men is welhaast geneigd de conclusie te trekken dat financiële participatie van werknemers niet echt past in die landen waar de partijen in het arbeidsbestel een grote mate van institutionele samenwerking kennen. Zou dit te maken kunnen hebben [met het gegeven] dat in dergelijke stelsels instrumenten die betrokkenheid van werknemers pogen te realiseren op basis van economische en op individueel eigenbelang gebaseerde principes met een zekere argwaan worden bekeken? Of is het zo dat binnen dergelijke stelsels de mening heeft postgevat dat men al voldoende mogelijkheden heeft gecreëerd om betrokkenheid van werknemers binnen de onderneming te ontwikkelen en er dus geen behoefte meer is aan extra stimulerende middelen?'81

Het is in die zin treffend dat het wetsvoorstel Eerlijk Delen precies in een tijd komt waarin de mening postvat dat Nederland te veel richting het Angelsaksische model is doorgeslagen. ${ }^{82}$ Geconfronteerd met deze trend zoekt het wetsvoorstel Eerlijk Delen de oplossing voor de achterblijvende lonen binnen ditzelfde model, op basis van de gedachte: als de winsten van bedrijven in toenemende mate naar aandeelhouders toevloeien, dan moeten werknemers ook maar aandeelhouder worden. In combinatie met de gedachte dat werknemers een andere mindset hebben dan de overige aandeelhouders, denkt de initiatiefnemer twee vliegen in één klap te slaan. Werknemers zullen nu meedelen in de hoge winsten die de afgelopen decennia zijn uitgekeerd, én zij zullen de zeggenschapsrechten die gekoppeld zijn aan het aandeelhouderschap (via de OR) uitoefenen op een manier die het 'doorgeschoten aandeelhouderskapitalisme' van een tegenkracht zal voorzien en het langetermijnsucces van de onderneming zal dienen. Werknemers moeten dus zowel profiteren van de winsten die de onderneming genereert, als ervoor zorgen dat de winstuitkeringen gematigd worden in het belang van het langetermijnsucces van de onderneming. Tussen deze twee doelen lijkt zich een tegenstrijdigheid voor te doen, waarbij een uitspraak van

79. E. Poutsma \& W. de Nijs, Aandelenparticipatie en winstdeling in Europa, TvA (14) 1998, afl. 2, p. 161

80. Poutsma \& De Nijs 1998, p. 164. Het Rijnlandse model wordt gekenmerkt door een grote institutioneel verankerde betrokkenheid tussen overheid en bedrijfsleven (werkgevers en werknemers) en een hoog ontwikkelde institutionele medezeggenschap.

81. Poutsma \& De Nijs 1998, p. 164.

82. Zo verscheen in 2019 een serie in het NRC, getiteld 'Hoe repareren we het kapitalisme?' 
Einstein voor de geest komt: 'Je kunt een probleem niet oplossen met de denkwijze die het probleem heeft veroorzaakt.' In tegenstelling tot het wetsvoorstel Eerlijk Delen zoekt het wetsvoorstel Eerlijk Beslissen de oplossing voor een herwaardering van de werknemer als stakeholder en het stimuleren van langetermijnwaardecreatie in de onderneming juist via het Rijnlandse model, namelijk binnen de overlegstructuren van het ondernemingsrecht.

\section{Het recente verleden - afname van de relevantie van de factor arbeid op meerdere niveaus}

In het recente verleden is een aantal trends waar te nemen die duiden op de afname van de relevantie van de factor arbeid op meerdere niveaus. Zo loopt de representativiteit van de vakbonden al jaren terug en is de Wet op de Publiekrechtelijke Bedrijfsorganisatie onder het kabinet-Rutte II opgeheven. In de memorie van toelichting valt in dit kader te lezen:

'Sinds de oprichting van het stelsel van bedrijfslichamen hebben enkele grote veranderingen plaatsgevonden, zowel in de markt als in de maatschappij, die de positie van bedrijfslichamen hebben beïnvloed. (...) [Ondernemers zijn] zelfstandiger geworden en [hun] organisatiegraad [is] gedaald. Ook heeft de sturende rol van de overheid in het economisch verkeer plaatsgemaakt voor een situatie waarin de overheid de voorwaarden schept waaronder ondernemers onderling concurreren en waarbij overheidsingrijpen enkel aan de orde is indien sprake is van marktfalen. ${ }^{93}$

Is het achterblijven van de lonen op de reële prijzen een vorm van marktfalen? Een rapport van de Rabobank uit 2018 concludeerde dat het reëel besteedbaar inkomen van huishoudens sinds 1977 nauwelijks is toegenomen, en achterblijft bij de groei van de totale economie. De opstellers van het rapport spreken over 'een fundamentele verschuiving van het belang van arbeid naar het belang van kapitaal'. ${ }^{84}$ Ook in het ondernemingsrecht is deze verschuiving te bespeuren. Hierboven viel reeds te lezen dat de wijzigingen in de structuurregeling waren ingegeven door de wens om de aandeelhouder bevoegdheden terug te geven, terwijl de oorspronkelijke structuurregeling nu juist de gelijkheid tussen de factoren arbeid en kapitaal had willen benadrukken. Opvallend is voorts dat de corporate governance rapporten in Nederland allemaal rondom dezelfde hoofdrolspelers draaien: de raad van bestuur ( $\mathrm{RvB})$, de $\mathrm{RvC}$ en de AV. Eerdere commissies die zich over de verhoudingen in de onderneming uitspraken, zoals de commissie-Valkhoff, de commissie-Witteveen en de commissie-Verdam, expliciteerden de rol van de onderneming ten opzichte van de samenleving, werknemers en het algemeen

83. Kamerstukken II 2013/14, 33910, nr. 3, p. 2.

84. M. Badir, Besteedbaar inkomen van huishoudens staat al bijna veertig jaar vrijwel stil, Utrecht: Rabobank/RaboResearch 2020. belang nog in hun werk, en zagen dit als centraal thema. ${ }^{85} \mathrm{De}$ commissie-Peters koos in 1997 echter voor een benadering waarin deze elementen bewust buiten beschouwing werden gelaten:

'De Commissie heeft zich bij haar werkzaamheden gericht op die aspecten van Corporate Governance die het samenspel van en het evenwicht tussen toezicht, leiding en kapitaalverschaffers binnen de vennootschap bepalen. $\mathrm{Zij}$ heeft andere aspecten zoals de relatie tot de samenleving, de werknemers, de klanten en sociale- en milieuaspecten geen onderwerp van beraad gemaakt. ${ }^{96}$

De commissie beargumenteerde deze keuze door te wijzen op haar takkopdracht, die immers zag op de behandeling van de positie van kapitaalverschaffers. Bovendien werd gewezen op de bestuurstaak, die impliciet inhield dat al deze aspecten en belangen door het bestuur worden meegewogen. ${ }^{87}$ Aan de beperkte benadering die door de commissie-Peters werd gekozen, hoeft op zichzelf niet heel veel betekenis te worden gehecht, zij het niet dat het werk van deze commissie volop in de aandacht van de politiek kwam te staan en de basis zou vormen van vele corporategovernancecodes. Door deze keuze bleef een bespreking van het borgen van andere aspecten, zoals de relatie van de onderneming tot de samenleving en werknemers, en de relatie van de onderneming tot sociale en milieuaspecten, structureel in de marge wanneer het over corporate governance ging. Dit is een duidelijke afwijking van de meer integrale benadering die na de Tweede Wereldoorlog decennialang centraal had gestaan. Belangrijke elementen die tijdenlang vervlochten waren in discussies over ondernemingsbestuur kwamen zo meer los te staan van het centrale onderwerp van het ondernemingsrecht van de 21 ste eeuw: corporate governance. In de debatten over dit onderwerp werd de werknemer, die zich in de voorafgaande decennia een noemenswaardige plek in de samenleving had weten te veroveren, naar de zijlijn verwezen. Zo degradeerde de werknemer van gelijkwaardige gesprekspartner in de SER, de bedrijfstak en de onderneming tot een van de stakeholders waarmee het bestuur rekening moet houden in zijn takuitoefening. Dit is tot op de

85. J. Valkhof e.a., De hervorming van de onderneming. Herziening van het vennootschapsrecht in verband met medezeggenschap in en toezicht op de onderneming (rapport van de dr. Wiardi Beckman Stichting), Amsterdam: De Arbeiderspers 1959, H.J. Witteveen e.a., Open ondernemerschap. De groei van de onderneming en het vennootschapsrecht (geschriften van de Teldersstichting), Den Haag: Martinus Nijhoff 1962 en Herziening van het ondernemingsrecht; rapport van de commissie o.l.v. P.J. Verdam, Den Haag: Staatsuitgeverij 1967.

86. Commissie Corporate Governance, Corporate Governance in Nederland: de veertig aanbevelingen, 25 juni 1997, p. 3.

87. Commissie Corporate Governance 1997, p. 3. Vgl. H. de Groot, Partijautonomie en solidariteit in het ondernemingsrecht gezien door een corporate governance-bril, in: M.W. Hesselink, C.E. de Perron \& A.F. Salomons (red.), Privaatrecht tussen autonomie en solidariteit, Den Haag: Boom Juridische uitgevers 2003, p. 76: 'De medezeggenschap van werknemers komt in het rapport niet aan de orde. Dat kan men de commissie niet kwalijk nemen, daar dit buiten haar opdracht viel, maar het lijkt mij in moderne tijden een onacceptabele omissie.' 
dag van vandaag onveranderd gebleven, getuige de nieuwste versie van de Corporate Governance Code:

'De verhouding tussen de vennootschap en haar werknemers(-vertegenwoordigers) is bij wet geregeld. In de Code komt deze verhouding aan bod in bepalingen die betrekking hebben op cultuur en de contacten tussen de raad van commissarissen en het medezeggenschapsorgaan.'

Ook in de praktijk rondom de structuurregeling is een degradatie van de positie van werknemers te bespeuren. Van Roosmalen en Koster wezen er recentelijk op dat de structuurregeling niet langer aansluit op de economische werkelijkheid. Zij deden onderzoek naar de toepassing van de structuurregeling bij grote AEX-genoteerde ondernemingen van Nederlandse origine of met veel activiteiten in Nederland. ${ }^{88}$ Hieruit bleek dat er op topholdingniveau nog nauwelijks beursgenoteerde structuurvennootschappen zijn, terwijl deze regeling nu juist voor dergelijke grote vennootschappen is geschapen. Mogelijke oorzaak hiervan is dat de structuurregeling wel van toepassing is verklaard op een van de onderliggende groepsmaatschappijen van deze concerns. Ook wijzen de auteurs op het veelvuldig gebruik van de 'Nederland-constructie'. Tussen de buitenlandse moedermaatschappij en de grote Nederlandse dochter(s) wordt dan een Nederlandse subholding geschoven. Deze Nederlandse vennootschap richt zich met name op het beheer van de aandelen van de Nederlandse groepsmaatschappijen. Het (verlichte) structuurregime wordt van toepassing verklaard op deze subholding, waardoor alle 'grote' dochtermaatschappijen zijn vrijgesteld van toepassing van het structuurregime. Bijgevolg dient slechts bij de subholding een verplichte $\mathrm{RvC}$ met goedkeuringsbevoegdheid van belangrijke besluiten van het bestuur te worden ingesteld. ${ }^{89}$ Door de Nederland-constructie verliest de factor arbeid op twee fronten aan invloed. Ten eerste kunnen de werknemers ingevolge de structuurregeling slechts nog invloed uitoefenen op de benoeming van commissarissen van de Nederlandse subholding, terwijl alle grote groepsmaatschappijen zijn vrijgesteld van toepassing van de structuurregeling. Als de subholding van de concernleiding geen wezenlijke rol krijgt toebedeeld in de besluitvorming binnen het concern, betekent dit dat de in de structuurregeling besloten medezeggenschap evenals het toezicht op het concernbeleid worden 'uitgehold'.$^{90}$ Ten tweede is de hoogste OR binnen het concern, de centrale ondernemingsraad (COR), op grond van artikel 33 lid 3 WOR niet langer de overlegpartner van de concernleiding, maar van het bestuur van de Nederlandse subholding of een personeelsdirecteur. Deze subholding wordt vaak als 'doorgeefluik' van de beslissingen van de topholding gezien, waardoor de invloed die de COR kan uitoefenen sterk afhangt van de invloed die het bestuur en de $\mathrm{RvC}$ van de subholding

88. Van Roosmalen \& Koster 2019, p. 15-36.

89. Ontleend aan: S.M. Bartman, A.F.M. Dorresteijn \& M. Olaerts, Van het concern, Deventer: Wolters Kluwer 2020, par. 4.7.2.

90. Bartman, Dorresteijn \& Olaerts 2020, par. 4.7.2. kunnen uitoefenen. ${ }^{91}$ Van Roosmalen en Koster concluderen dat het doel van de structuurregeling, dat is gelegen in meer democratie en sterker toezicht binnen de grote onderneming, vaak niet meer behaald wordt. Volgens hen is de structuurregeling niet meer in staat om op adequate wijze te voorzien in de in Nederland gewortelde gedachte dat werknemers zich tot de belangrijkste stakeholders van de onderneming mogen scharen en derhalve invloed aan de top kunnen uitoefenen. ${ }^{92}$

De wetsvoorstellen voor een eerlijke economie haken in op het sentiment dat de balans in Nederland te ver is doorgeschoten ten voordele van de factor kapitaal en ten nadele van de factor arbeid, waardoor een groeiende ongelijkheid ontstaat in de samenleving. Dat dit sentiment politiek breed wordt gedeeld, blijkt uit de uitlatingen in 2019 van een politieke tegenhanger van de SP: minister-president Mark Rutte (VVD). Hij keerde zich tegen het uitblijven van loonsverhogingen, terwijl de winsten van bedrijven 'tegen de plinten klotsen'. Volgens hem bestaat er sinds de Tweede Wereldoorlog 'een ongeschreven afspraak' dat 'als het met de bedrijven goed gaat, het goed gaat met het personeel'. ${ }^{3} \mathrm{Zo}_{\mathrm{o}}$ is in het afgelopen jaar de politieke consensus over het verhogen van het minimumloon zo groot geworden dat het zomaar eens onderdeel zou kunnen worden van een nieuw regeerakkoord dat in 2021 gesloten zal moeten worden. $^{94}$

\section{Conclusie}

Als politiek links en rechts het erover eens zijn dat bedrijven zich meer gelegen moeten laten liggen aan hun werknemers, dan is de vervolgvraag hoe men dit wil bereiken. Het wetsvoorstel Eerlijk Delen en het wetsvoorstel Eerlijk Beslissen vormen slechts twee van de vele opties om het gedrag van bedrijven en hun aandeelhouders te sturen. Een verplichte aanpassing van het aandeelhoudersbestand met een brede werknemersvertegenwoordiging is daarin mijns inziens een vergaand voorstel. Gelijktijdige invoering van instemmingsrechten aangaande strategische onderwerpen levert niet alleen een gedeeltelijke overlap aan rechten op, maar ook vergaande gevolgen voor de rechtsgang aangaande deze besluiten. Wie de wetsvoorstellen individueel en in hun samenhang weegt, zal deze dan ook te licht bevinden. De wetsvoorstellen blijken op vele punten nog niet goed doordacht, variërend van het toepassingsbereik en de verschillen tussen BV's en NV's (en hun beursgenoteerde varianten) tot vragen over de toepassing van de regelingen in de praktijk, zoals de financiering van de aandelen en de moeilijkheden die de royeerbaarheid van certificaten met zich mee kan brengen in combinatie met het jaarlijks verdelen van certificaten over werknemers naar rato van het aantal gewerkte uren. De daadwerkelijk ingediende versie

91. Van Roosmalen \& Koster 2019, p. 30-31 met nadere verwijzingen. Vgl. Bartman, Dorresteijn \& Olaerts 2020, par. 5.4.7.

92. Van Roosmalen \& Koster 2019, p. 31 en 33.

93. T. Borst \& J. Tieleman, Volgens Rutte blijven de salarissen achter bij de winsten. Klopt dat?, de Volkskrant 17 juni 2019.

94. G. Herderscheê \& M. de Ruiter, Hoe links en rechts het eens werden over een hoger minimumloon, de Volkskrant 11 november 2020. 


\section{Maandblad}

van het wetsvoorstel Eerlijk Delen voorziet maar gedeeltelijk in de opvang van deze kritiekpunten.

De wens om tot versterking van de positie van werknemers te komen is echter heel toepasselijk voor het tijdsgewricht, waarin de factor arbeid op verschillende niveaus aan betekenis heeft ingeboet. In het neoliberale tijdperk werden zo veel mogelijk onderwerpen tot het domein van de markt gerekend, en zijn veel sociale voorzieningen afgebouwd. Het aantal terreinen waarop de factor arbeid op macroniveau zijn invloed kan doen gelden, is derhalve geslonken, net zoals zijn achterban. Het mesoniveau van de publiekrechtelijke bedrijfsorganisatie is inmiddels non-existent geworden. En waar tot halverwege de vorige eeuw vooral de zeggenschap van werknemers emancipeerde en hun sociaaleconomische status werd verhoogd door een uitruil van een lager loon ten gunste van de maatschappij (wederopbouw en verzorgingsstaat), is dat vanaf de jaren tachtig omgeslagen. De relevantie van vennootschapsrechtelijke medezeggenschap bij grote ondernemingen is afgenomen en er heeft een uitruil plaatsgevonden van een lager loon ten gunste van de aandeelhouder. Het is deze ontwikkeling waar het drieluik aan wetsvoorstellen zich tegen afzet. De vorm die de wetsvoorstellen Eerlijk Delen en Eerlijk Beslissen nu hebben aangenomen, lijkt mij echter te radicaal en te ondoordacht om serieuze navolging te krijgen in het ondernemingsrecht. Maar wellicht dat deze voorstellen de pennen in beweging zullen brengen om na te denken over subtielere manieren om een verschuiving in de machtsbalans in grote ondernemingen teweeg te brengen, zoals een verplichte winstdelingsregeling dan wel toegang tot het enquêterecht of agenderingsrecht voor de OR bij structuurvennootschappen. 